\title{
PENGEMBANGAN DESAIN MOTIF BATIK REYOG BULKIYO DALAM MENDUKUNG DESA WISATA KEMLOKO, KECAMATAN NGLEGOK, KABUPATEN BLITAR
}

\author{
Nurul Ratnawati, I Nyoman Ruja, Neni Wahyuningtyas, Khofifatu Rohmah Adi \\ nurul.ratnawati.fis@um.ac.id \\ Program Studi Pendidikan IPS, Fakultas IImu Sosial, Universitas Negeri Malang \\ Diterima 1 September 2021, dipublikasikan 25 Oktober 2021
}

\begin{abstract}
Abstrak
Desa Kemloko merupakan daerah dengan kekayaan alam dan budaya yang melimpah. Potensi inilah yang kemudian dieksplor dan dijadikan sebagai aset pengembangan Desa Wisata Kemloko. Potensipotensi tersebut kemudian diklasifikasikan menjadi beberapa program wisata Desa Kemloko yang ditawarkan pada masyarakat umum. Saat ini Desa Kemloko sedang gencar mengembangkan desa wisata tersebut. Oleh sebab itu dukungan komoditi oleh-oleh khas atau cinderamata yang mampu memikat wisatawan sangat diperlukan. Salah satu karya seni khas yang telah ada di Desa Kemloko dan berpotensi untuk dijadikan oleh-oleh adalah kain batik reyog bulkiyo. Kain batik reyog bulkiyo ini telah mendapatkan hak paten yang diajukan oleh Pokdarwis Desa Kemloko. Namun, jika dilihat dari desainnya, motif batik reyog bulkiyo masih tradisional, warna-warna yang kurang bervariasi sehingga kesannya monoton, cepat membosankan, kuno, dan tua. Ironis, ketika masyarakat memiliki potensi lokal yang bernilai ekonomis tetapi tidak dikembangkan. Berdasar permasalahan di atas, fokus kegiatan pengabdian ini adalah memberikan pengetahuan dan pemahaman tentang seputar batik, teknik membatik, dan bagaimana pengembangan motif batik kepada kelompok sasaran yaitu pokdarwis. Metode pelaksanaan untuk merealisasikan pemecahan masalah dalam pengabdian masyarakat ini dilakukan tiga tahapan yaitu: 1) tahap persiapan meliputi penyusunan jadwal, peserta, tempat, bahanbahan; 2) tahap pelaksanaan meliputi pelatihan dan pendampingan membatik; dan 3) tahap tindak lanjut meliputi perencanaan batik \& pengembangan produk unggulan. Hasil dari kegiatan ini berupa inovasi kain batik reyog bulkiyo baru dengan motif-motif baru. Kain batik pertama terdiri dari kombinasi 3 motif yaitu penari reyog bulkiyo, slompret, dan sinar rembulan. Sedangkan kain batik kedua terdiri dari dua motif yaitu motif penari reyog bulkiyo dan barong.
\end{abstract}

Kata Kunci: Kain Batik, Reyog Bulkiyo, Desa Kemloko, Motif Batik

\section{PENDAHULUAN}

Kemloko adalah salah satu desa yang berada di dalam wilayah Kecamatan Nglegok Kabupaten Blitar, Jawa Timur. Desa Kemloko terdiri dari 2 Dusun, yaitu Dusun Kemloko dan Dusun Kluwut. Desa Kemloko memiliki luas wilayah 327,13 Ha, sebelah utara berbatasan dengan Desa Penataran dan Desa Ngoran, sebelah selatan berbatasan dengan Desa Krenceng dan Desa Bangsri. Sedangkan sebelah timur berbatasan dengan Kelurahan Nglegok dan sebelah barat berbatasan dengan Desa Dayu.

Berdasarkan data administrasi pemerintahan desa (2016) jumlah penduduk Desa Kemloko 4.758 jiwa, dengan rincian 2.227 laki-laki dan 2.531 perempuan. Di lihat dari tingkat pendidikannya, mayoritas masyarakat telah mengenyam pendidikan. Usia pra sekolah $14 \%$, lulusan SD sejumlah $25 \%$, SMP 19 $\%$, SMA $22 \%$, PT 9\%, sedangkan yang tidak tamat SD 11\%. Sebagian besar masyarakatnya bermata pencaharian sebagai petani. Sektor pertanian mencapai $68 \%$, sektor industri $25,5 \%$, sektor lainnya seperti pemerintahan, perdagangan, jasa angkutan dan lainnya sebesar $6,5 \%$.

Desa Kemloko merupakan daerah dengan kekayaan alam dan budaya yang melimpah. Potensi inilah yang kemudian dieksplor dan dijadikan sebagai aset pengembangan Desa Wisata Kemloko. Hal tersebut sejalan dengan pernyataan Sumarmi et al., (2018) yang menjelaskan bahwa salah satu strategi dan terobosan desa wisata menitikberatkan pada eksplorasi mendalam terhadap potensi yang 
ada di desa seperti potensi alam, budaya, sejarah ataupun aktivitas sehari-hari warga desa. Potensi alam, sosial, dan budaya Desa Kemloko antara lain budidaya ikan hias koi, pengrajin gula jawa dan gula semut, kelompok tani kakao, jaranan sido rukun, reyog bulkiyo, reyog sawunggaling, wayang kulit, dan solawat jedor.

Potensi-potensi tersebut kemudian diklasifikasikan menjadi beberapa program wisata Desa Kemloko yang ditawarkan pada masyarakat umum. Jenis wisata tersebut yaitu: outbond \& fun game, pelatihan edukasi, wisata ikan hias koi, kampung wisata edukasi, wisata budaya, dan wisata peternakan. Perlu diketahui, saat ini Desa Kemloko sedang gencar-gencarnya mengembangkan desa wisata. Oleh sebab itu dukungan komiditi oleh-oleh khas atau cinderamata yang mampu memikat wisatawan sangat diperlukan.

Salah satu karya seni khas yang telah ada di Desa Kemloko dan berpotensi untuk dijadikan oleholeh adalah kain batik reyog bulkiyo seperti yang terlihat pada gambar 1 . Kain batik reyog bulkiyo merupakan kain batik yang motifnya terinspirasi dari budaya lokal tari reyog bulkiyo. Tari ini merupakan tari yang menceritakan semangat pertempuran pasukan Diponegoro melawan Belanda (Towaf \& Sukamto, 2018). Berbagai motif batik di Indonesia telah dikembangkan dengan inspiarsi yang berasal dari kekayaan alam, sejarah dan budaya lokal masing-masing daerah (Prahastutiningtyas \& Rizkiantono, 2016). Misalnya Nautica \& Sayatman (2019) merancang motif batik dari potensi daerah Kabupaten sidoarjo yaitu Monumen Jayandaru (icon udang dan bandeng), lontong kupang, Candi Pari, dsb. Marta et al., (2018) perancangan motif batik kontemporer yang terinspirasi kesenian reyog ponorogo. Utami et al., (2018) mengembangkan motif batik dari relief Candi Kidal.

Pengembangan desain batik berbasis kearifan lokal secara berkesinambungan nantinya diharapkan dapat dilanjutkan menjadi berbagai wujud produk unggulan dan cinderamata seperti tempat pensil, tempat tissue, tas, taplak meja, gantungan kunci, dsb. Kain batik reyog bulkiyo ini telah mendapatkan hak paten yang diajukan oleh Pokdarwis Desa Kemoloko. Namun setelah mendapat hak paten kain batik ini disimpan dan dibiarkan begitu saja tidak ada tindak lanjut. Hal tersebut terjadi karena keterbatasan pengetahuan, teknik, dan pengembangan motif batik, sehingga dibiarkan apa adanya. Disamping itu, pembuat batik (pembatik) reyog bulkiyo belum sempat mewariskan pengetahuan kepada generasi berikutnya telah meninggal dunia. Bahkan masyarakat dalam pun belum banyak yang mengetahui tentang kain tersebut. Jika dilihat dari desainnya, motif batik reyog bulkiyo masih tradisional, dengan warna-warna yang kurang bervariasi sehingga kesannya monoton, cepat membosankan, kuno, dan tua. Ironis, ketika masyarakat memiliki potensi lokal yang bernilai ekonomis tetapi tidak dikembangkan. Oleh karena itu, dirasa perlu melakukan pengembangan desain batik reyog bulkiyo guna mendukung desa wisata serta mendukung roda perekeonomian masyarakat setempat.

Berdasarkan analisis situasi di atas, permasalahan yang dihadapi mitra yaitu kelompok sadar wisata (Pokdarwis) adalah: a) Terdapat kain batik reyog bulkiyo yang merupakan karya seni batik khas Desa Kemloko, namun batik tersebut belum dapat memberikan dampak lebih kepada masyarakat. Hal ini terjadi karena keterbatasan masyarakat tentang pengetahuan, teknik, dan pengembangan motif batik. b) Motif batik reyog bulkiyo terkesan monoton, warna-warna yang kurang bervariasi, kuno, dan tua, oleh sebab itu perlu ada pengembangan motif supaya lebih memikat seluruh kalangan. c) Batik reyog bulkiyo belum dikenal baik oleh masyarakat, oleh karena itu perlu ada solusi untuk mengenalkan batik reyog bulkiyo kepada masyarakat luas.

\section{METODE}

Metode pelaksanaan untuk merealisasikan pemecahan masalah dalam pengabdian masyarakat ini dilakukan tiga tahapan yaitu: 1) tahap persiapan; 2) tahap pelaksanaan; dan 3) tahap tindak lanjut seperti yang terlihat pada Gambar 2. 


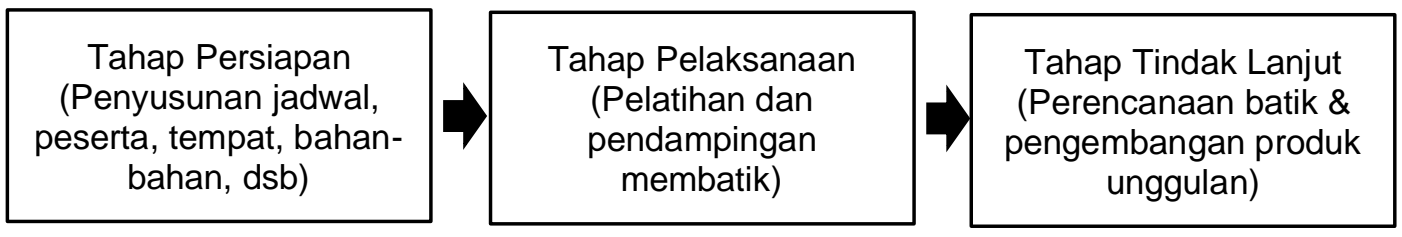

Gambar 1 Metode Pelaksanaan Pengabdian

Tahap persiapan, persiapan yang dilakukan meliputi: penyusunan jadwal pengabdian, penentuan peserta pengabdian, mempersiapkan tempat pengabdian, dan mempersiapkan bahanbahan yang diperlukan dalam pengabdian.

Tahap pelaksanaan, pelaksanaan kegiatan pengabdian masyarakat ini dijabarkan dalam tahap sebagai berikut: 1) Identifikasi komponen atau unsur-unsur yang terdapat dalam kesenian tari reyog bulikyo yang dapat dijadikan ide pengembangan motif batik. Unsur-unsur tersebut misalnya instrumen tari, tokoh yang berperan dalam tari, dan unsur lainnya. 2) Membahas unsur-unsur mana yang akan dipilih menjadi motif batik dalam FGD (Focus Group Discussion) yang melibatkan perangkat desa, ahli desain batik, pegaiat kesenian reyog bulkiyo, dan kelompok sadar wisata (pokdarwis). 3) Hasil dari kegiatan FGD tersebut kemudian dirancang dan digambar dalam bentuk sektsa. Sketsa yang dibuat tentunya tidak sama persis dengan unsur tari reyog bulkiyo, tanpa mengurangi makna filosofis reyog bulkiyo sketsa akan ditambahkan dengan unsur-unsur keindahan lainnya. 4) Membuat canting cap sesuai dengan sketsa ke pengrajin. 5) Mendampingi dan melatih kelompok sadar wisata untuk membatik.

Tahap tindak lanjut, setelah melakukan pendampingan dan pelatihan pembuatan batik, peserta pelatihan diharapkan mampu merencanakan bisnis batik dan mengembangkan produk unggulan berbahan dasar batik dalam mendukung desa wisata Kemoloko.

\section{HASIL DAN PEMBAHASAN}

\section{Kegiatan Pengembangan}

Kegiatan pengembangan desain motif batik reyog bulkiyo dalam mendukung desa wisata Kemloko, Kecamatan Nglegok, Kabupaten Blitar dilaksanakan selama tiga kali pertemuan. Pertemuan pertama FGD pada hari Sabtu, 15 Agutus 2020 yang melibatkan pihak perangkat Desa Kemloko, pegiat tari reyog bulkiyo, ahli desain batik, pokdarwis, dan beberapa masyarakat setempat. Kegiatan FGD ini dilakukan dengan tujuan untuk eksplorasi ide, mencari beberapa komponen atau unsur dari tarian reyog bulkiyo yang potensial untuk dikembangkan menjadi motif batik. FGD ini menghasilkan keputusan bahwa terpilih empat unsur tarian reyog yaitu unsur penari, unsur alat musik, unsur busana, dan ceita yang akan dikembangkan menjadi motif batik reyog bulkiyo. Motif tersebut yaitu: 1) motif penari reyog bulkiyo, 2) motif slompret, 3) motif barong, dan 4) motif sinar rembulan. Motif-motif tersebut dikombinasikan sehingga menghasilkan dua macam kain batik reyog bulkiyo.

\section{Dari Komponen Tari Reyog Bulkiyo ke Motif}

Reyog Bulkiyo merupakan warisan budaya tak benda yang lahir di Desa Kemloko Kecamatan Nglegok Kabupaten Blitar. Sebagai tarian, reyog bulkiyo memiliki makna yang dalam yaitu mengajarkan berbagai kebaikan yang harus dilakukan manusai selama hidup di dunia dan mengajarkan pula bahwa kebaikan harus selalu ditegakkan di atas kejahatan. Tarian ini menggambarkan cerita tentang perang perlawanan antara prajurit Pangeran Diponegoro dengan Belanda. Sehingga pesan moral dalam tarian ini mengisahkan sebuah perjuangan untuk melawan kejahatan.

Karakteristik tarian reyog bulkiyo dapat dilihat dari komponen 1) ragam gerak, 2) alat musik, 3) busana, dan 4) kisah atau riwayat bulkiyo. Gerakan tari reyog bulkiyo terdiri dari pembuka, inti, dan penutup. Alat musik yang mengiringi pementasan tarian terdiri dari 10 macam alat musik. Pada pementasan reyog bulkiyo, masing-masing penari yaitu penari rontek, penari pangarep, dan penari prajurit menggunakan busana khusus. Ciri yang kuat pada tarian ini juga bisa dililihat dari pengisahan sejarah bulkiyo, terutama saat adegan penari pangarep beradu pedang yang merupakan adengan perkelahian dua orang yang berseteru. 
Berdasarkan komponen tersebut, kemudian dikembangkan menjadi motif batik. Pertama, motif penari reyog bulkiyo, motif ini dikembangkan dan terinpirasi dari penari reyog bulkiyo. Kedua, motif slompret, motif ini dikembangkan dari komponen alat musik tari reyog bulkiyo. Alat musik ini termasuk alat musik tiup yang berbentuk seperti terompet. Suara slompret paling dominan saat pementasan reyog bulkiyo. Ketiga, motif barong, diambil dari busana yaitu jarik atau jarit barong yang digunakan penari. Keempat motif sinar rembulan, motif sinar rembulan terinspirasi dari pemnetasan tari ini yang dilaksanakan pada malam hari. Sinar rembulan memberikan cahaya terang dan indah, sehingga bisa mempengaruhi suasana hati para penonton saat melihat pementasan. Motif-motif tersebut terdapat pada gambar 1 dan 2 berikut.

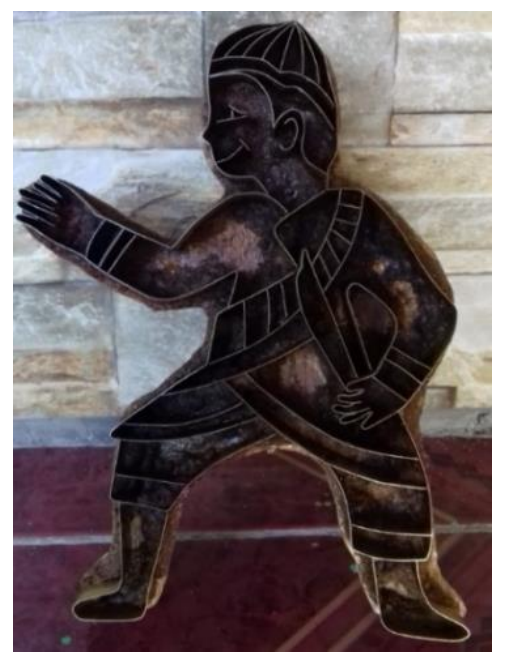

Gambar 2 Motif Penari Reyog Bulkiyo

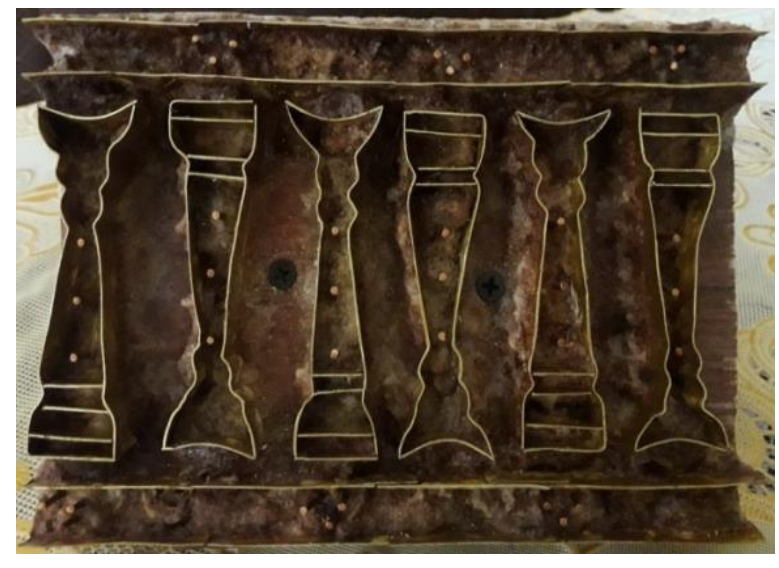

(a)

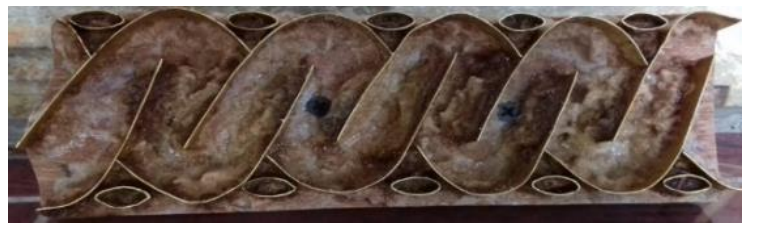

(b)

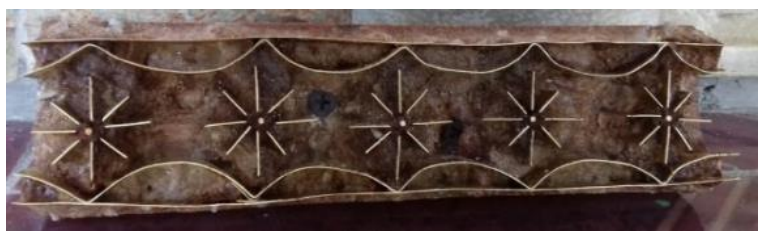

(c)

Gambar 3 (a) Motif Slompret; (b) Motif Barong; (c) Motif Sinar Rembulan

\section{Proses Pembuatan Kain Batik}

Pelatihan pembuatan batik dilakukan selama 2 hari yaitu pada hari Sabtu dan Minggu tanggal 23 dan 24 Agustus 2020 di depan halaman rumah Mbah Jadi. Kegiatan pelatihan ini dihadiri 24 peserta, dimulai pukul 09.00 s.d 17.00. Dalam kegiatan ini, selain berkejasama dengan pihak Desa Kemloko, ketua pengabdian juga bekerjasama dengan Gallery Batik Soendari.

Kegiatan hari pertama yaitu mencap dan mencanting kain (lihat gambar 3). Sebagai wujud kepedulian dan dukungan perangkat desa, turut hadir dalam pembukaan pelatihan Bapak Muh. Dhofir selaku Kepala Desa Kemloko untuk menyukseskan acara ini. Dalam sambutannya beliau menyampaikan bahwa "senang dan bangga karena tim dari Universitas Negeri Malang bersedia 
berkolaborasi dengan masyarakat desa untuk mengembangkan motif batik khas Desa Kemloko yaitu batik reyog bulkiyo".
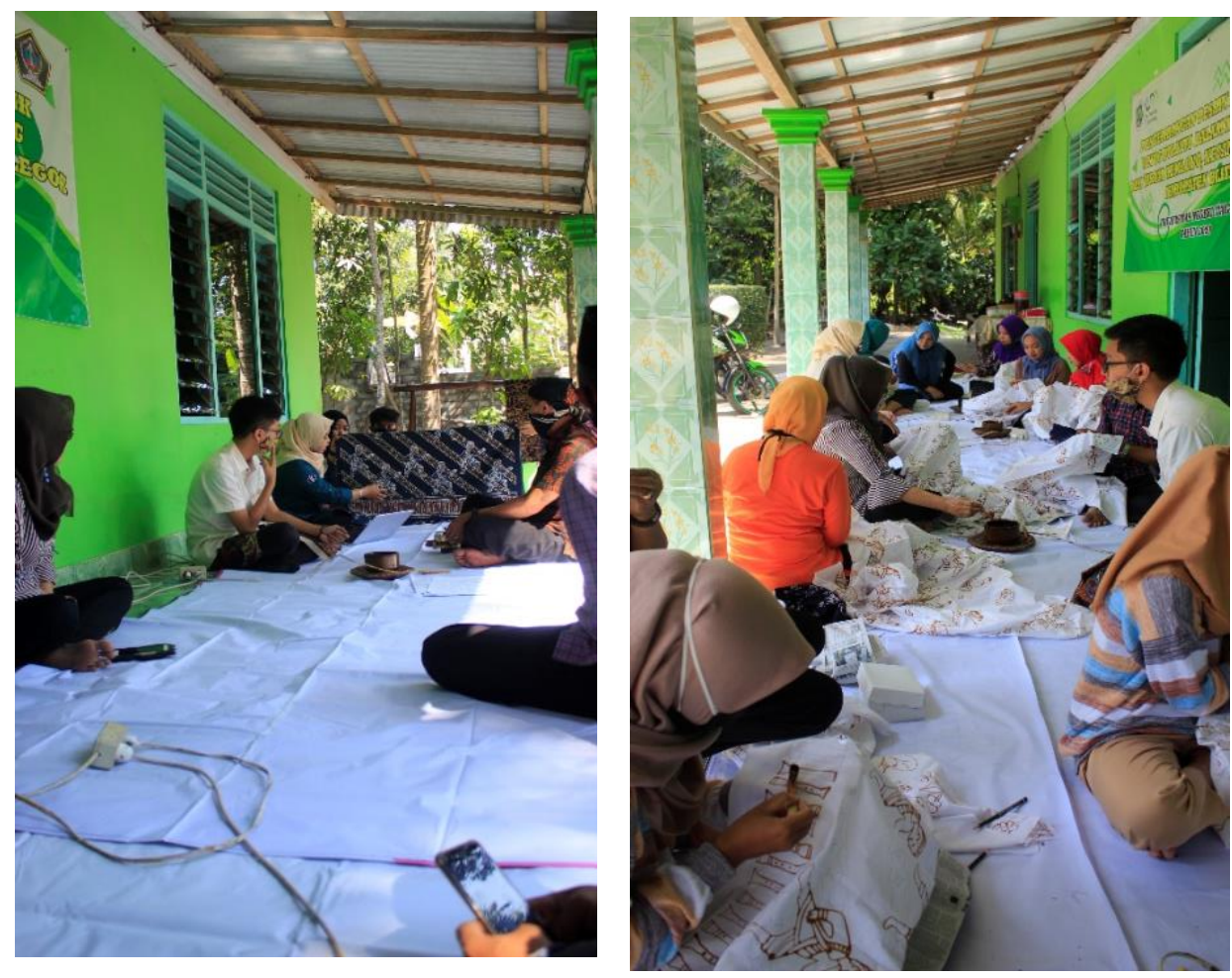

Gambar 4 Prose Mencap dan Mencanting

Kegiatan hari kedua yaitu pewarnaan kain, penguncian warna dengan waterglaas, penjemuran, pelorodan, pencucian, dan penjemuran kembali (lihat gambar 4). Kegiatan ini berhasil membuat peserta semangat dan antusias dalam membatik, karena peserta belum pernah mengenal teknik-teknik dalam membatik sebelumnya. Sementara itu, salah satu peserta pelatihan menyatakan dengan mengikuti pelatihan yang diadakan UM ini ia mendapatkan pengetahuan, pengalaman, dan ilmu baru dalam hal membatik, ujarnya. Melalui kegiatan ini diharapkan akan ada inovasi-inovasi baru pengembangan desain motif batik reyog bulkiyo yang lebih variatif lagi seraya memperkenalkan budaya khas daerah (reyog bulikyo) lewat kain batik ini.
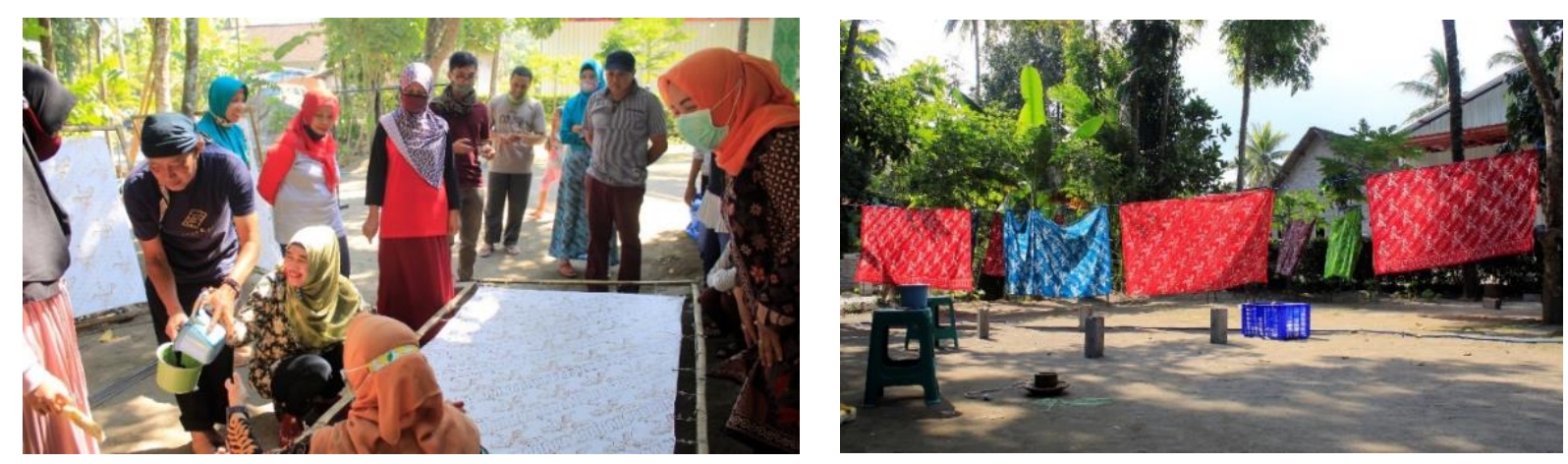

Gambar 5 Kegiatan Pewarnaan \& Penjemuran 
Hasil batik reyog bulkiyo terdiri dari dua variasi baru (lihat gambar 5). Motif baru pertama terdiri dari kombinasi 3 motif yaitu penari reyog bulkiyo, slompret, dan sinar rembulan. Sedangkan motif baru kedua terdiri dari dua motif yaitu motif penari reyog bulkiyo dan barong.
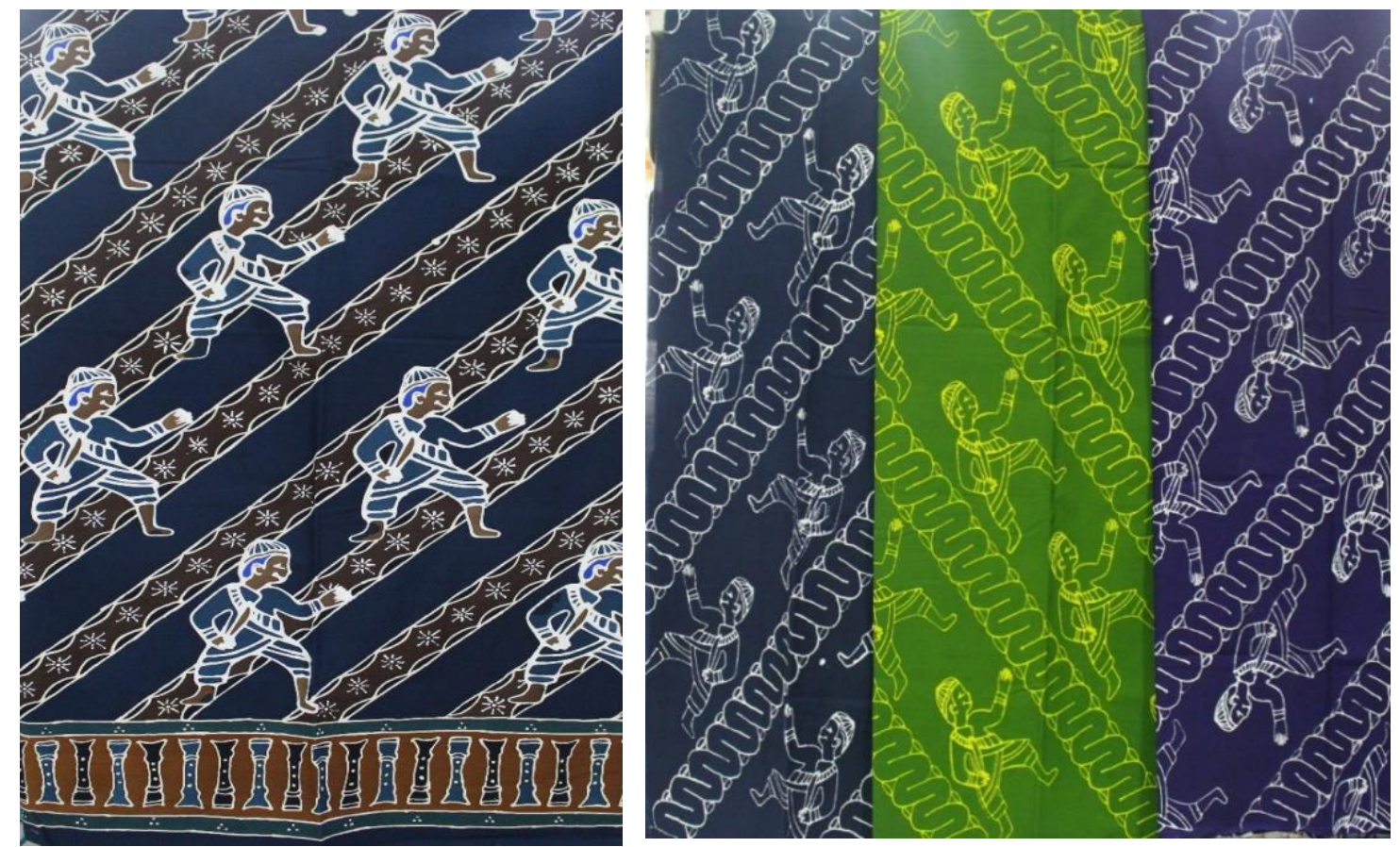

Gambar 6 Motif Baru Pertama dan Kedua Batik Reyog Bulkiyo

\section{KESIMPULAN}

Pendampingan membatik dengan menggunakan material kearifan lokal menjadi langkah strategis pengembangan budaya batik bagi masyarakat. Hasil pengabdian menunjukkan bahwa pengabdian membatik menjadi salah satu media yang baik untuk mengenalkan budaya daerah serta dapat mempererat kerjasama baik dengan pihak desa maupun kelompok pegiat tari reyog bulkiyo. Dari hasil proses kegiatan pengabdian ini, maka didapatkan hasil berupa kain batik dengan motif reyog bulkiyo yang dibuat oleh ibu-ibu pegiat tari reyog bulkiyo. Hasil karya tersebut kemudian di presentasikan dan dibahas bersama-sama sebagai bagian dari evaluasi. Peserta mengikuti proses tahapan dalam membatik dengan baik. Kegiatan yang dilakuakn mulai dari awal yaitu membuat sketsa, mencap, mencanting, pewarnaan, hingga proses pengeringan.

Saran yang dapat menjadi masukan bagi pihak-pihak yang terkait antara lain: Pertama, dibutuhkan semangat dan keberanian untuk untuk terus melakukan inovasi. Oleh karena itu pihak desa perlu terus memompa semangat ibu-ibu yang tergabung dalam pegiat tari reyog bulkiyo untuk tidak berhenti setelah kegiatan pengabdian ini, melainkan terus mengembangkan inovasi produk batik dengan cara mulai memproduksinya. Harus berani untuk mulai memproduksi. Kedua, membuka wawasan dengan banyak melihat referensi dan selera masyarakat terkini untuk menjadi sumber ide pengembangan motif.

\section{UCAPAN TERIMA KASIH}

Ucapan terima kasih kami sampaikan kepada Bapak Muh. Dhofir selaku Kepala Desa Kemloko yang telah mendukung secara penuh dalam proses persiapan, pelaksanaan, dan penutupan kegiatan pengabdian kepada masyarakat ini. Ucapan terima kasih juga kami sampaikan kepada kelompok pegiat tari reyog bulkiyo, pokdarwis, seluruh masyarakat serta pihak-pihak yang tidak dapat kami sebutkan satu-persatu yang telah berpartisipasi secara aktif dalam pelaksanaan kegiatan pengabdian yang telah kami lakukan. Tak lupa ucapan terima kasih yang sebesar-besarnya kepada Mbah Jadi dan 
Pengembangan Desain Motif Batik Reyog Bulkiyo dalam Mendukung Desa Wisata Kemloko, Kecamatan Nglegok...

para pegiat tari reyog bulkiyo yang telah menampilkan tari reyog bulkiyo dalam acara penutupan kegiatan pengabdian yang kami lakukan.

\section{DAFTAR PUSTAKA}

Marta, M., Karnadi, D. H., \& Renaningtyas, L. (2018). Perancangan Motif Batik Kontemporer yang Terinspirasi Kesenian Reog Ponorogo. Jurnal DKV Adiwarna, 1(12), 1-11.

Nautica, S., \& Sayatman, S. (2019). Perancangan Motif Batik dari Potensi Daerah Kabupaten Sidoarjo sebagai Cara Melestarikan dan Memperkaya Motif Batik Sidoarjo. Jurnal Sains dan Seni ITS, 8(1), 84-90. https://doi.org/10.12962/j23373520.v8i1.41627.

Prahastutiningtyas, Y., \& Rizkiantono, R. E. (2016). Perancangan Motif Batik Berkarakter Kediri. Jurnal Sains dan Seni ITS, 5(2), 237-242. https://doi.org/10.12962/j23373520.v5i2.20766.

Sumarmi, Syamsul Bachri, \& Elya Kurmiawati. (2018). Pendampingan Pemetaan Potensi Pertanian Lokal dan Pengelolaannya dalam Mendukung Agro Ekowisata Kecamatan Kandangan Kabupaten Kediri. Jurnal Praksis dan Dedikasi Sosial, 1, 125-134.

Towaf, S. M., \& Sukamto, M. (2018). Reyog Bulkiyo as a Cultural Potential in The Natural Laboratory of Sounthern Slopes of Kelud Volcano and its Use for Social Studies Learning Based on Environment. Proceedings of the International Conference on Learning Innovation (ICLI 2017). International Conference on Learning Innovation (ICLI 2017), Malang, Indonesia. https://doi.org/10.2991/icli-17.2018.42.

Utami, I. W. P., Jati, S. S. P., \& Sapto, A. (2018). Relief Candi Kidal sebagai Inspirasi Pengembangan Motif Batik Khas Desa Kidal untuk Pemberdayaan Masyarakat. Jurnal Praksis dan Dedikasi Sosial, 1(1), 29-38. 